\title{
Analysis of Physical, Thermal, and Structural Properties of Biofield Energy Treated Molybdenum Dioxide
}

\author{
Mahendra Kumar Trivedi ${ }^{1}$, Rama Mohan Tallapragada ${ }^{1}$, Alice Branton ${ }^{1}$, Dahryn Trivedi ${ }^{1}$, \\ Gopal Nayak ${ }^{1}$, Omprakash Latiyal ${ }^{2}$, Snehasis Jana ${ }^{2, *}$ \\ ${ }^{1}$ Trivedi Global Inc., Henderson, USA \\ ${ }^{2}$ Trivedi Science Research Laboratory Pvt. Ltd., Bhopal, Madhya Pradesh, India
}

Email address:

publication@trivedisrl.com (S. Jana)

\section{To cite this article:}

Mahendra Kumar Trivedi, Rama Mohan Tallapragada, Alice Branton, Dahryn Trivedi, Gopal Nayak, Omprakash Latiyal, Snehasis Jana. Analysis of Physical, Thermal, and Structural Properties of Biofield Energy Treated Molybdenum Dioxide. International Journal of Materials Science and Applications. Vol. 4, No. 5, 2015, pp. 354-359. doi: 10.11648/j.ijmsa.20150405.21

\begin{abstract}
Molybdenum dioxide $\left(\mathrm{MoO}_{2}\right)$ is known for its catalytic activity toward reforming hydrocarbons. The objective of this study was to evaluate the effect of biofield energy treatment on physical, thermal, and structural properties in $\mathrm{MoO}_{2}$. The $\mathrm{MoO}_{2}$ powder sample was divided into two parts, one part was remained as untreated, called as control, while the other part was subjected to Mr. Trivedi's biofield energy treatment and called as treated. Both control and treated samples were investigated using X-ray diffraction (XRD), thermogravimetric analysis (TGA), and Fourier transform infrared (FT-IR) spectroscopy. The XRD data exhibited that the biofield treatment has altered the lattice parameters, unit cell volume, density and molecular weight of the treated sample as compared to the control. The TGA study revealed that the onset temperature of thermal degradation of $\mathrm{MoO}_{2}$ was reduced from $702.87^{\circ} \mathrm{C}$ to $691.92^{\circ} \mathrm{C}$. Besides, the FT-IR spectra exhibited that the absorption band corresponding to $\mathrm{Mo}=\mathrm{O}$ stretching vibration was shifted to lower wavenumber i.e. $975 \mathrm{~cm}^{-1}$ (control) to 970 $\mathrm{cm}^{-1}$ in treated sample. Hence, above results suggested that biofield energy treatment has altered the physical, thermal, and structural properties in $\mathrm{MoO}_{2}$ powder. Therefore, the biofield treatment could be applied to modify the catalytic properties of $\mathrm{MoO}_{2}$ in pharmaceutical industries.
\end{abstract}

Keywords: Molybdenum Dioxide, Biofield Energy Treatment, X-ray Diffraction, Thermogravimetric Analysis, Fourier Transform Infrared Spectroscopy

\section{Introduction}

Molybdenum is a well-known element, around $80 \%$ is utilized in steel industries to improve the corrosion resistance [1]. The molybdenum compounds have long been use for numerous applications. Molybdenum has oxidation states varying from +2 to +6 , among them, oxides exist in two forms i.e. molybdenum (IV) and molybdenum (VI) oxide. Molybdenum (IV) oxide $\left(\mathrm{MoO}_{2}\right)$ has high electrical conductivity like metals due to presence of delocalized electrons in its valence band [2]. Due to this, $\mathrm{MoO}_{2}$ is used in rechargeable lithium ion batteries as anode material [3]. In addition, it is also used in solid oxide fuel cell (SOFC) as anode material because it has high fuel flexibility and electrical conductivity $[4,5]$. Recently, $\mathrm{MoO}_{2}$ has gained significant attention due to its catalytic activity towards reforming hydrocarbons. The catalytic action of $\mathrm{MoO}_{2}$ is governed by metallic site i.e. $\mathrm{Mo}^{+4}$. It was reported that the metallic site dissociates the hydrogen $\left(\mathrm{H}_{2}\right)$ and produce active hydrogen atoms. After that, the active hydrogen atoms binds with the surface oxygen and form Bronsted acid functional groups [6]. For industrial applications, the physical, thermal, and morphological properties of $\mathrm{MoO}_{2}$ plays a crucial role. Currently, the physical and thermal properties of $\mathrm{MoO}_{2}$ are controlled via various processes such as reduction of $\mathrm{MoO}_{3}$ [7], hydrothermal process [8], and thermal evaporation [9], etc. All these process are either require costly equipment setup or high temperature conditions to obtain the desired properties. Thus, it is important to search an alternative approach which can modify the physical and thermal properties of $\mathrm{MoO}_{2}$ powder.

The energy exists in various forms and there are several ways to transfer the energy from one place to another such as electrochemical, electrical and thermal etc. Similarly, the 
human nervous system consists of neurons, which have the ability to transmit information and energy in the form of electrical signals. Due to this, a human has the ability to harness the energy from environment/universe and can transmit it to any object (living or non-living) around the Globe. The object(s) always receive the energy and responded into useful way that is called biofield energy. This process is termed as biofield energy treatment. The National Center for Complementary and Alternative Medicine (NCCAM) has considered the biofield treatment (or healing therapy) under subcategory of energy therapies [10]. Mr. Trivedi's unique biofield energy treatment is known as The Trivedi Effect ${ }^{\circledR}$. Recently, Mr. Trivedi's biofield energy treatment is known to alter the atomic, physical and thermal characteristics in several metals [11-13] and ceramics [14-16] in material science field. After considering the outstanding consequences with biofield energy treatment on ceramics and metals, this work was designed to evaluate the effect of biofield treatment on the physical, thermal, and structural properties of the $\mathrm{MoO}_{2}$ using X-ray diffraction (XRD), thermogravimetric analysis (TGA), and Fourier transform infrared (FT-IR) spectroscopy.

\section{Materials and Methods}

The $\mathrm{MoO}_{2}$ powder was purchased from Sigma Aldrich, USA. The procured powder was equally divided into two parts. One part was remained untreated, called as control. While, other part was in sealed pack, handed over to $\mathrm{Mr}$. Trivedi for biofield energy treatment under standard laboratory conditions. Mr. Trivedi provided the treatment through his energy transmission process to the treated sample without touching the sample and this part was coded as treated. After that, the control and treated samples were characterized using XRD, TGA, and FT-IR techniques.

\subsection{XRD Study}

The XRD analysis of control and treated $\mathrm{MoO}_{2}$ samples was accomplished on Phillips, Holland PW 1710 X-ray diffractometer system. The X-ray of wavelength 1.54056 $\times 10^{-10} \mathrm{~m}$ was used. From the XRD diffractogram, the peak intensity counts, $\mathrm{d}$ value $(\AA)$, full width half maximum $(\mathrm{FWHM})\left(\theta^{\circ}\right)$, relative intensity $(\%)$ values were obtained. The PowderX software was used to compute the lattice parameter and unit cell volume of the control and treated $\mathrm{MoO}_{2}$ samples. The Scherrer equation was used to compute the crystallite size (D) as following:

$$
\mathrm{D}=\mathrm{k} \lambda /(\mathrm{b} \operatorname{Cos} \theta)
$$

Here, $b$ is full width half maximum (FWHM) of XRD peaks, $\mathrm{k}=0.94$, and $\lambda=1.54056 \AA$.

The percentage change in crystallite size was calculated using following formula:

$$
\% \text { change in crystallite size }=\left[\left(D_{t}-D_{c}\right) / D_{c}\right] \times 100
$$

Where, $D_{c}$ and $D_{t}$ are crystallite size of control and treated powder samples respectively.

\subsection{Thermal Analysis}

The thermal analysis of $\mathrm{MoO}_{2}$ powder was done using TGA-DTG. For that, Mettler Toledo simultaneous TGADTG instrument was used. The samples were heated from room temperature to $900^{\circ} \mathrm{C}$ with a heating rate of $10^{\circ} \mathrm{C} / \mathrm{min}$ under nitrogen atmosphere.

\subsection{FT-IR Spectroscopy}

The FT-IR analysis of control and treated $\mathrm{MoO}_{2}$ samples were carried out on Shimadzu's FT-IR (Japan) with frequency range of $4000-500 \mathrm{~cm}^{-1}$. The analysis was accomplished to evaluate the effect of biofield treatment on dipole moment, force constant and bond strength in chemical structure.

\section{Results and Discussion}

\subsection{XRD Study}

The XRD technique is a quantitative and non-destructive technique, which have been widely used to study the crystal structure and its parameters for a given compound. The XRD pattern of control and treated $\mathrm{MoO}_{2}$ is given in Fig 1 . Ths XRD pattern of control sample showed the crystalline peaks at Bragg angle (20) $26.02^{\circ}, 36.97^{\circ}, 53.51^{\circ}, 60.25$, and $66.67^{\circ}$. The peaks were fitted well with the monoclinic crystal structure according to Joint committee on powder diffraction standards (JCPDS file no. 65-5758 with a space group of P21/c [17]. Furthermore, the treated sample showed the peaks at $2 \theta 26.04^{\circ}, 37.00^{\circ}, 53.55^{\circ}, 60.29$, and $66.68^{\circ}$. It indicated that all XRD peaks were slightly shifted toward higher angles in the treated sample as compared to the control, after biofield energy treatment. In order to study the crystal structure parameters, the PowderX software was used and lattice parameters, unit cell volume, density, and molecular weight were computed. The results are presented in Table 1. The data showed that the lattice parameters "a" and "c" of treated sample were decreased from $5.649 \AA$ (control) to $5.643 \AA$ and $5.650 \AA$ (control) to $5.645 \AA$, respectively. Also, the reduction in lattice parameters led to decrease the unit cell volume from $13.292 \times 10^{-23} \mathrm{~cm}^{3}$ (control) to $13.268 \times 10^{-23} \mathrm{~cm}^{3}$. Schwertmann et al. reported that the reduction in lattice parameter of unit cell led to shift the XRD peaks toward higher angles [18]. It was also reported that the XRD peaks can shift to the higher side if larger radii atoms are replaced by smaller radii atoms [19]. The decrease in lattice parameter and unit cell volume were supported by shifting of XRD peaks toward higher angles. Thus, based on the shifting of XRD peaks and reduction in the lattice parameters "a" and "c", it is presumed that the biofield treatment might induce compressive stress in treated $\mathrm{MoO}_{2}$. Due to this, an internal strain might induce in treated $\mathrm{MoO}_{2}$ after biofield treatment and that possibly resulted in alteration of lattice parameters and unit cell volume. 
Nevertheless, the crystallite size was found to be same in control and treated sample as $70.8 \mathrm{~nm}$. Besides, the reduction in unit cell volume caused an increase in density from $6.450 \mathrm{~g} / \mathrm{cc}$ (control) to $6.462 \mathrm{~g} / \mathrm{cc}$ in treated sample.

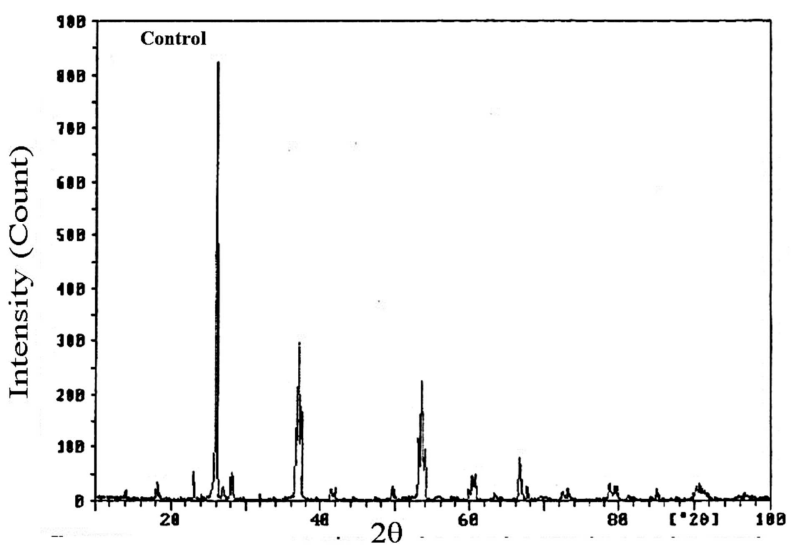

On the contrary, the molecular weight of the treated $\mathrm{MoO}_{2}$ powder was decreased from 129.10 to $128.87 \mathrm{~g} / \mathrm{mol}$. Hence, the XRD data suggested that biofield energy treatment has altered the physical properties of $\mathrm{MoO}_{2}$.

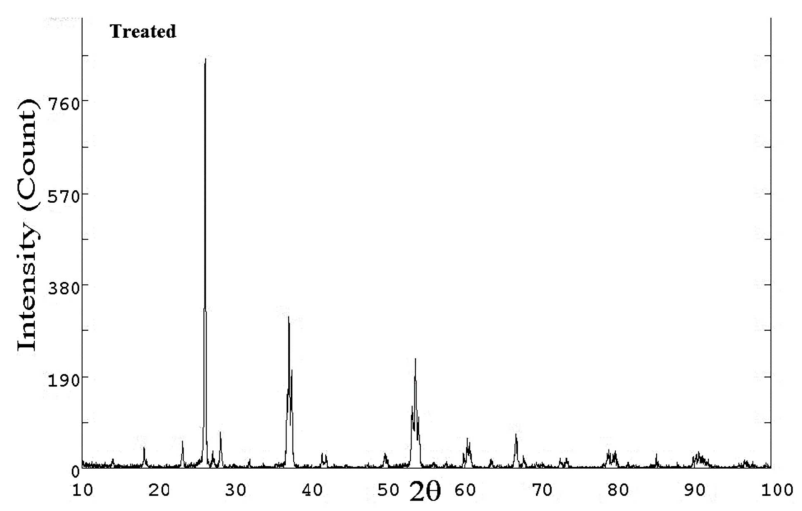

Fig. 1. X-ray diffractogram of molybdenum dioxide powder.

Table 1. X-ray diffraction analysis of molybdenum dioxide powder.

\begin{tabular}{|c|c|c|c|c|c|c|}
\hline Group & $\begin{array}{l}\text { Lattice parameter } \\
\text { "a" }(\AA)\end{array}$ & $\begin{array}{l}\text { Lattice parameter } \\
\text { "cc" (§) }\end{array}$ & $\begin{array}{l}\text { Unit cell volume } \\
\left(\times 10^{-23} \mathrm{~cm}^{3}\right)\end{array}$ & $\begin{array}{l}\text { Density } \\
\text { (g/cc) }\end{array}$ & $\begin{array}{l}\text { Molecular weight } \\
(\mathrm{g} / \mathrm{mol})\end{array}$ & $\begin{array}{l}\text { Crystallite } \\
\text { size (nm) }\end{array}$ \\
\hline Control & 5.6491 & 5.650 & 13.292 & 6.45065 & 129.10 & 70.8 \\
\hline Treated & 5.6436 & 5.645 & 13.268 & 6.46222 & 128.87 & 70.8 \\
\hline
\end{tabular}

\subsection{Thermal Analysis}

Thermal analysis of $\mathrm{MoO}_{2}$ was accomplished using TGADTG system. The TGA curve of control and treated $\mathrm{MoO}_{2}$ is shown in Fig 2. The control TGA showed that the sample started to gain the weight around $336.5^{\circ} \mathrm{C}$, and continues till $444.5^{\circ} \mathrm{C}$. In this process, the weight of control sample was increased by approximately $9.5 \%$ as compared to its initial weight. Naouel et al. reported that the weight gain by $\mathrm{MoO}_{3}$ sample in TGA was due to its oxidation [20] Zhang et al. reported that the theoretical weight gain during oxidation of $\mathrm{MoO}_{2}$ to $\mathrm{MoO}_{3}$ is $12.5 \%$ [21].

Nevertheless, the treated sample started to gain the weight at around $386.6{ }^{\circ} \mathrm{C}$ and continue to gain till $657.4{ }^{\circ} \mathrm{C}$. In this process the weight of the treated sample was increased by $7.6 \%$ with respect to its weight at $306.6^{\circ} \mathrm{C}$. It suggested that the onset temperature for oxidation of treated sample was decreased by $8.8 \%$ as compared to the control. It could be due to decrease in thermal stability of treated $\mathrm{MoO}_{2}$ sample after biofield energy treatment. It is assumed that the energy absorbed by the treated sample through biofield energy treatment, probably alter the bond strength of $\mathrm{M}=\mathrm{O}$. Due to which, the treated $\mathrm{MoO}_{2}$ may convert into $\mathrm{MoO}_{3}$ at lower temperature. Nevertheless, the data also showed that the control sample started to lose its weight at onset temperature $702.87^{\circ} \mathrm{C}$ and ended at temperature $825^{\circ} \mathrm{C}$. The weight loss at this temperature could be due to sublimation of the $\mathrm{MoO}_{3}$ compound $[22,23]$. Furthermore, the treated sample showed the onset and endset temperature at $691.92^{\circ} \mathrm{C}$ and $825^{\circ} \mathrm{C}$ respectively. The data suggested that the onset temperature of treated sample was reduced as compared to the control. Thus, it is assumed that the intermolecular interaction of the treated sample may get reduced after the biofield treatment and that might be responsible for the reduction of onset temperature in the treated sample as compared to control. Further, the reduction in intermolecular interaction in treated sample may reduce its thermal stability. Besides, the peak width i.e. the difference of onset and endset temperature, was calculated as $122.13^{\circ} \mathrm{C}$ in the control while, it was increased to $133.08{ }^{\circ} \mathrm{C}$ in the treated sample. The data also exhibited that in this sublimation process, the control and treated samples were lost around $71.50 \%$ and $61.83 \%$ of their respective initial weight. Moreover, the rate of weight loss was decreased from $1.50 \times 10^{-5} \mathrm{~g} / \mathrm{s}$ (control) to $0.88 \times 10^{-5} \mathrm{~g} / \mathrm{s}$ in treated $\mathrm{MoO}_{2}$ sample (Table 2). It indicated that the rate of weight loss of treated $\mathrm{MoO}_{2}$ during decomposition process was decreased by $41.05 \%$ as compared to the control. Hence, TGA data suggested that biofield energy treatment has altered the thermal properties of $\mathrm{MoO}_{2}$.

Table 2. TGA analysis of molybdenum dioxide powder.

\begin{tabular}{lll}
\hline Parameter & Control & Treated \\
\hline Peak onset & 702.87 & 691.92 \\
Peak & 792.11 & 790.54 \\
Endset & 825.00 & 825.00 \\
Peak width & 122.13 & 133.08 \\
Percent change in weight at Onset & 109.52 & 105.44 \\
Percent change in weight at endset & 38.02 & 43.61 \\
Change in weight percent & -71.50 & -61.83 \\
Percent change in weight/width & -0.585 & -0.464 \\
Rate of weight loss $\left(\times 10^{-5} \mathrm{~g} / \mathrm{s}\right)$ & -1.506 & -0.887 \\
Percent change in rate of weight loss & - & -41.05 \\
\hline
\end{tabular}




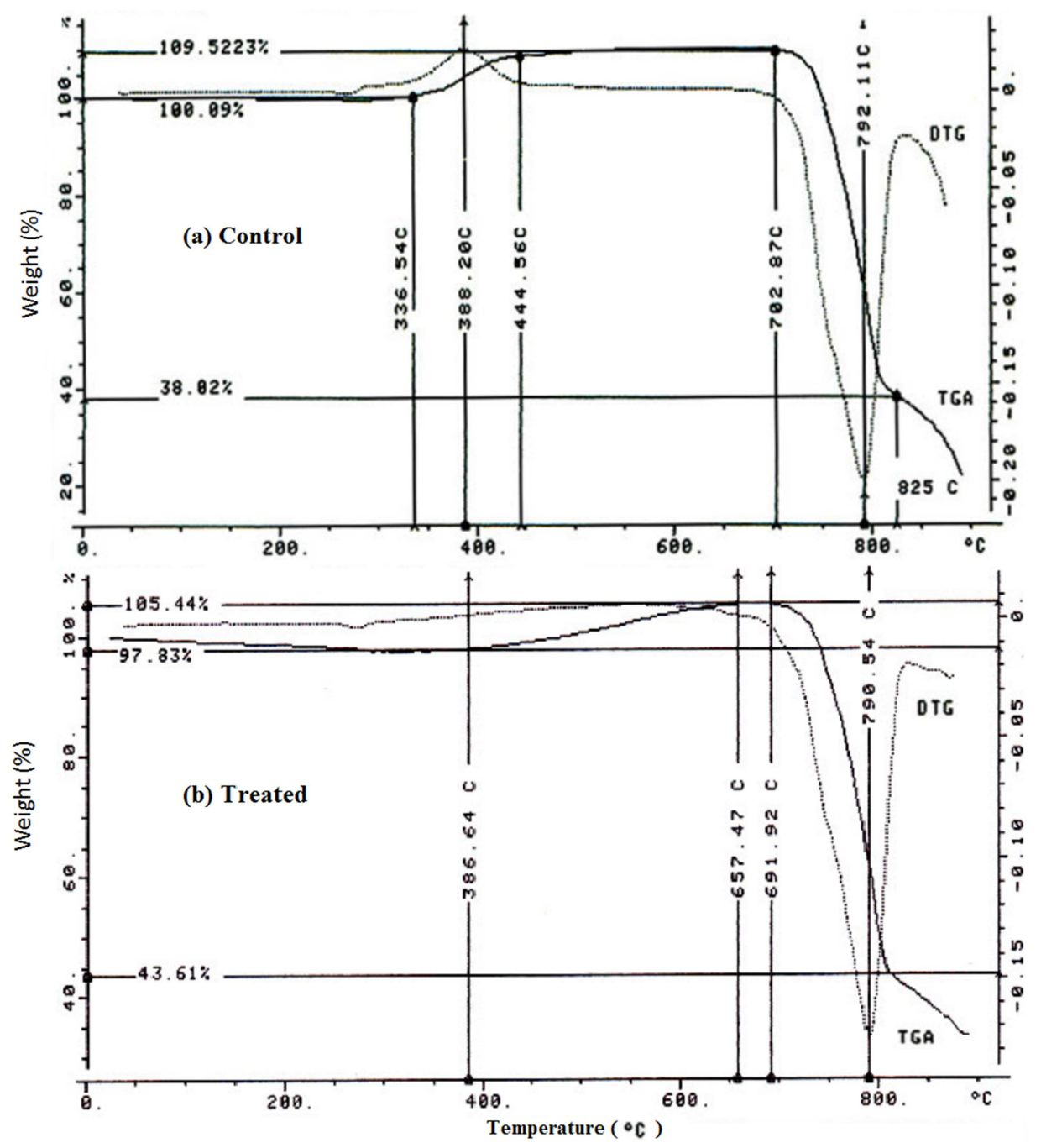

Fig. 2. TGA thermogram of molybdenum dioxide powder.

\subsection{FT-IR Spectroscopy}

The FT-IR spectra of control and treated $\mathrm{MoO}_{2}$ samples are presented in Fig 3. The control sample showed the absorption band at wavenumber $975 \mathrm{~cm}^{-1}$, which was assigned to symmetric stretching modes of the double terminal $\mathrm{Mo}=\mathrm{O}$ bond [24]. It was shifted to lower wavenumber $970 \mathrm{~cm}^{-1}$ in the treated sample after biofield treatment. Previously, our group reported that biofield energy treatment had altered the Ti-O bond length in barium titanate $\left(\mathrm{BaTiO}_{3}\right)$ [25]. The stretching vibration wavenumber $(v)$ of a bond is directly related to the bond force constant $(\mathrm{k})$ as follow:

$$
v=\frac{1}{2 \pi c} \sqrt{\frac{k}{\mu}}
$$

Here, $\mu$ is effective mass of atoms, which form the bond.

From the above equation, it can be inferred that the increase of bond force constant leads to increase the wavenumber in FT-IR and vice versa. Thus, the decrease in wavenumber corresponding to $\mathrm{Mo}=\mathrm{O}$ stretching vibration in the treated sample suggested that its bond strength might reduce after biofield energy treatment. In addition, the band observed at $466 \mathrm{~cm}^{-1}$ in control, was shifted to lower wavenumber $450 \mathrm{~cm}^{-1}$ in the treated sample, which could be due to metal oxygen bond. In addition, the treated sample also showed the absorption bands at 547 and $715 \mathrm{~cm}^{-1}$, which were absent in control sample. It was reported that the band around $715 \mathrm{~cm}^{-1}$ is the characteristic peak of the asymmetric stretching vibrations of the $\mathrm{O}-\mathrm{Mo}-\mathrm{O}$ bonds [26]. Based on the above data, it is assumed that biofield energy treatment probably acted at bonding level to cause these modification. Furthermore, the reduction in bond strength in $\mathrm{M}=\mathrm{O}$ was also supported by the reduction in thermal stability of $\mathrm{MoO}_{2}$. Besides, in order to use $\mathrm{MoO}_{2}$ as catalyst in hydrocarbon, it's $\mathrm{Mo}=\mathrm{O}$ bond strength and thermal stability plays an important role. Hence, the modification of $\mathrm{M}=\mathrm{O}$ bond strength and thermal stability of $\mathrm{MoO}_{2}$ through biofield energy treatment could alter its catalytic activities. 


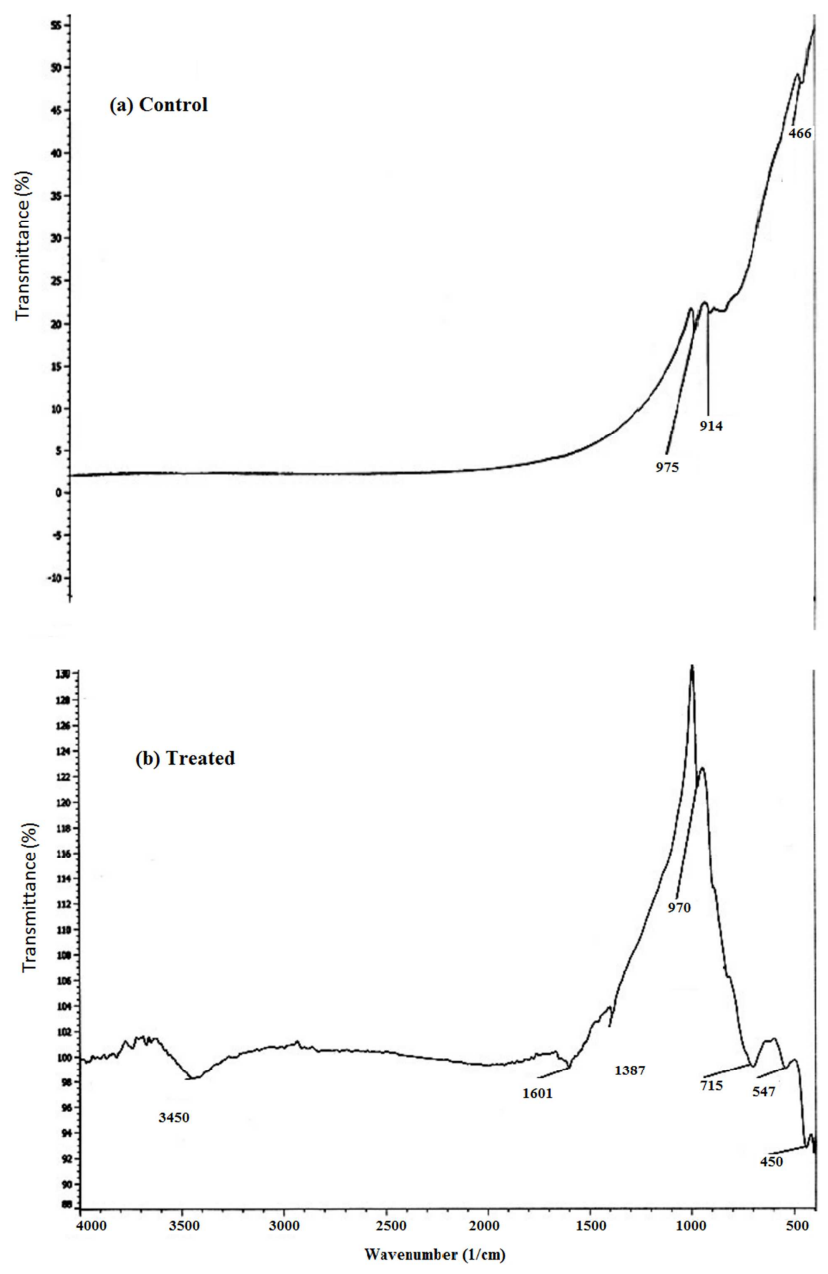

Fig. 3. FT-IR spectra of molybdenum dioxide powder.

\section{Conclusions}

The biofield treatment has reduced the lattice parameters and unit cell volume of monoclinic $\mathrm{MoO}_{2}$ powder. The XRD data showed the alteration in the lattice parameters, unit cell volume, density and molecular weight of the treated sample as compared to the control. The TGA study revealed that the onset temperature of thermal degradation of $\mathrm{MoO}_{2}$ was reduced from $702.87{ }^{\circ} \mathrm{C}$ to $691.92{ }^{\circ} \mathrm{C}$, which could be due to the reduction of thermal stability of treated sample as compared to the control. The rate of weight loss during degradation in treated sample was reduced by $41.05 \%$ as compared to the control. Besides, FT-IR spectra exhibited that the absorption band corresponding to $\mathrm{Mo}=\mathrm{O}$ stretching vibration was shifted from $975 \mathrm{~cm}^{-1}$ (control) to lower wavenumber i.e. $970 \mathrm{~cm}^{-1}$ in the treated sample, which could be due to reduction of strength of $\mathrm{Mo}=\mathrm{O}$ bond in the treated sample. Hence, overall data concluded that biofield energy treatment has significant impact on the physical, thermal, and structural properties of $\mathrm{MoO}_{2}$ powder. Therefore, the modification of thermal stability and bonding strength of treated $\mathrm{MoO}_{2}$ through biofield energy treatment could make it more useful in catalytic action as compared to the control.

\section{Acknowledgements}

Authors would like to acknowledge Dr. Cheng Dong of NLSC, Institute of Physics, and Chinese academy of sciences for permitting us to use Powder-X software for analyzing XRD results. The authors would also like to thank Trivedi Science, Trivedi Master Wellness and Trivedi Testimonials for their support during the work.

\section{References}

[1] Capus JM (2000) Metal Powders: A Global Survey of Production, Applications and Markets. 3rd Edition, Elsevier, Technology \& Engineering.

[2] Ellefson CA, Marin-Flores O, Ha S, and Norton MG (2012) Synthesis and applications of molybdenum (IV) oxide. J Mater Sci 47: 2057-2071.

[3] Shi Y, Guo B, Corr SA, Shi Q, Hu YS, and Heier KR (2009) Ordered mesoporous metallic $\mathrm{MoO}_{2}$ materials with highly reversible lithium storage capacity. Nano Lett 9: 4215-4220.

[4] Marin-Flores O, Turba T, Ellefson C, Wang K, Breit J, and Ahn J et al. (2010) Nanoparticle molybdenum dioxide: A highly active catalyst for partial oxidation of aviation fuels. Appl Catal B: Environ 98: 186-192.

[5] Marin Flores O, Turba T, Ellefson C, Scudiero L, Breit J, Norton $G$ et al. (2010) Nanoparticle molybdenum dioxide: a new alternative catalytic material for hydrogen production via partial oxidation of jet-a fuels. J Nanoelectron Optoe 5: 1-5.

[6] Belatel H, Al-Kandari H, Al-Khorafi F, and Katrib A (2004) The bifunctional catalytic properties of a partially $\mathrm{H}_{2}$-reduced $\mathrm{MoO}_{3}$. Catal Commun 5: 225-229.

[7] Kennedy MJ, and Bevan SC (1974) A kinetic study of the reduction of molybdenum trioxide by hydrogen. J LessCommons Metals 36: 23-30.

[8] Chen X, Zhang Z, Li X, Shi C, and Li X (2006) Selective synthesis of metastable $\mathrm{MoO}_{2}$ nanocrystallites through a solution-phase approach. Chem Phys Lett 418: 105-108.

[9] Irfan, So F, and Gao Y (2011) Photoemission spectroscopy characterization of attempts to deposit $\mathrm{MoO}_{2}$ thin film. Int $\mathrm{J}$ Photoenergy Volume 2011, Article ID 314702, 6 pages.

[10] Barnes PM, Powell-Griner E, McFann K, and Nahin RL (2004) complementary and alternative medicine use among adults: United States, 2002. Advanced Data, 343: 1-19.

[11] Trivedi MK, Tallapragada RM, Branton A, Trivedi D, Nayak G, et al. (2015) Potential impact of biofield treatment on atomic and physical characteristics of magnesium. Vitam Miner 3: 129.

[12] Trivedi MK, Nayak G, Patil S, Tallapragada RM, Latiyal O, et al.(2015) An evaluation of biofield treatment on thermal, physical and structural properties of cadmium powder. J Thermodyn Catal 6: 147.

[13] Trivedi MK, Patil S, Tallapragada RM (2013) Effect of bio field treatment on the physical and thermal characteristics of Silicon, Tin and Lead powders J Material Sci Eng 2: 125. 
[14] Trivedi MK, Patil S, Nayak G, Jana S, Latiyal O (2015) Influence of biofield treatment on physical, structural and spectral properties of boron nitride. J Material Sci Eng 4: 181.

[15] Trivedi MK, Nayak G, Patil S, Tallapragada RM, Latiyal O (2015) Studies of the atomic and crystalline characteristics of ceramic oxide nano powders after bio field treatment. Ind Eng Manage 4: 161.

[16] Trivedi MK, Tallapragada RM, Branton A, Trivedi D, Nayak G, et al. (2015) characterization of physical, thermal and structural properties of chromium (VI) oxide powder: Impact of biofield treatment. J Powder Metall Min 4: 128.

[17] Deng Z, Hu Y, Ren D, Lin S, Jiang H, and Li C (2015) Reciprocal hybridization of $\mathrm{moo}_{2}$ nanoparticles and few-layer $\mathrm{MoS}_{2}$ for stable lithium-ion batteries. Chem Commun 51: 13838-13841.

[18] Schwertmann U, and Cornell RM (2007) Iron oxides in the laboratory: preparation and characterization. John Wiley \& Sons.

[19] Kumar P and Kar M (2014) Effect of structural transition on magnetic and dielectric properties of $\mathrm{La}$ and $\mathrm{Mn} \mathrm{Co}$-substituted $\mathrm{BiFeO}_{3}$ ceramics. Mater Chem and Phys 148: 968-977.

[20] Naouel R, Touati F, and Gharbi N (2012) Control of the morphology of molybdenum dioxide nanoparticles. E-Journal of Chemistry 9: 233-239.

[21] Zhang $\mathrm{H}, \mathrm{Wu} \mathrm{T}$, Wang $\mathrm{K}, \mathrm{Wu} \mathrm{X}$, Chen $\mathrm{X}$, and Jiang $\mathrm{Y}$ et al. (2013) Uniform hierarchical $\mathrm{MoO}_{2} /$ carbon spheres with high cycling performance for lithium ion batteries. J Mater Chem A 1: 12038-12043.

[22] Sarno M, Garamella A, Cirillo C, and Ciambelli P (2014) $\mathrm{MoO}_{2}$ synthesis for LIBs. Chem Eng Transac 41: 307-312.

[23] Azurdia JA, McCrum A, and Laine RM (2008) Systematic synthesis of mixed-metal oxides in $\mathrm{NiO}-\mathrm{Co}_{3} \mathrm{O}_{4}, \mathrm{NiO}-\mathrm{MoO}_{3}$, and $\mathrm{NiO}-\mathrm{CuO}$ systems via liquid-feed flame spray pyrolysis. J Mater Chem 18: 3249-3258.

[24] Martos M, Morales J, Sanches L (2002) Mechanochemical synthesis of $\mathrm{Sn}_{12 \mathrm{x}} \mathrm{Mo}_{\mathrm{x}} \mathrm{O}_{2}$ anode materials for Li-Ion batteries. $\mathrm{J}$ Mater Chem 12: 2979-2984.

[25] Trivedi MK, Nayak G, Patil S, Tallapragada RM, Latiyal O, et al. (2015) Impact of biofield treatment on atomic and structural characteristics of barium titanate powder. Ind Eng Manage 4: 166.

[26] Baran EJ, Mormann TJ, Grocke HJ, and Jeitschko W (2001) Infrared and Raman spectra of $\mathrm{Hg}_{2} \mathrm{MoO}_{4}$ and $\mathrm{Hg}_{2} \mathrm{WO}_{4}$. J Raman Spectroscopy 32: 395-398. 